José del Valle*

\title{
Departments and disciplinary gatekeeping: The sociolinguistics of Spanish in US academia
}

https://doi.org/10.1515/ijsl-2020-2081

\begin{abstract}
In his contribution, José del Valle looks at the intersection of the sociolinguistic study of Spanish in the US and the transformations of Spanish language departments in higher education. Del Valle traces the history of the institutionalization of Spanish teaching and study and its effects on linguistic research's position within Spanish departments. Shifts in approaches to the use of language in social practice, and the growing demands on language units to act as service departments for language learners, has isolated scholars in those institutional homes from broader integration into sociolinguistic research.
\end{abstract}

Keywords: Spanish in the US, panhispanism, Hispanic sociolinguistics, language and cultural studies, Spanish departments

Our current understandings of language as social practice and sociolinguistics as a discipline have unfolded within complex disciplinary, academic, and professional structures. These include academic departments, which, through their curricular and hiring choices, can make or break careers; and professional associations, which, through their conferences, journals, and public statements, manage the field's inner tensions and favor research on certain dimensions of the object over others.

At the same time, both language and the institutions around it are always embedded in history. Disciplines, co-constitutive with such objects, emerge and develop in tandem with struggles over specific social needs and demands, alternative epistemic paradigms, and differential material conditions for the production and distribution of knowledge. Research on a language's history, for example, may very well be connected to a community's need to legitimize its status as a nation-state.

Having 31 years of experience in US academia, I have seen how US academic and professional institutions that focus on the study of the Spanish language replicate this institutionalization and compartmentalization. Departments of

*Corresponding author: José del Valle, The Graduate Center - The City University of New York (CUNY), 365 Fifth Avenue, New York, USA, E-mail: jdelvalle@gc.cuny.edu 
linguistics have enjoyed nominal centrality, but have favored inquiry on the structuration of the grammatical system and imposed conceptual and methodological constraints on the recognition of legitimate sociolinguistic research. Departments of anthropology, even when relegating the discipline's linguistic branch to marginal positions, have enabled a prominent institutional space for the study of language as social process (e. g. work on linguistic ideologies). Schools of education - especially due to the sociolinguistic complexity of the US student body - have aimed at understanding verbal interaction within educational settings.

Hispanic linguistics research exemplifies how the study of language and society has been sensitive, on one hand, to the sociopolitical contexts that determine the value and relevance of language and languages and, on the other, to how universities organize, teach, and promote research on language. A less noticed - or noticeable - contribution to sociolinguistics comes from within departments of modern languages and under the auspices of well-known journals and professional associations (e.g. the Modern Language Association). Here, I focus on "Spanish" departments ignoring the otherwise crucial distinction between autonomous, "stand alone" departments and those incorporated within larger ones such as romance, modern, or foreign languages.

\section{Pan-Hispanism and Spanish as a foreign language in the United States}

The American Association of Teachers of Spanish (AATS) was founded in 1917 (in 1944, it embraced Portuguese, becoming the AATSP) with the aim of institutionalizing the study of Spanish language and literature in the United States. The group of scholars behind this project had various intellectual and institutional links with nineteenth-century US Hispanism - Washington Irving, Longfellow, George Ticknor - and were connected to pan-Americanism (see Degiovanni 2018). Just a few months after founding the AATS, the association's leadership created Hispania, a journal that, to this day, performs a central role in shaping the study of Spanish, as well as Spanish and Latin American literature, in the United States. Surprisingly, or maybe not, the lead article of the first issue was written by Spanish philologist Ramón Menéndez Pidal (1869-1968), professor at the University of Madrid, director of Spain's prestigious Center for Historical Studies, distinguished member of Spain's language academy, and, crucially, one of the major intellectual architects of pan-Hispanism, a geopolitical project that promoted Spain's preeminence over its former colonies on the basis of the alleged existence and persistence of cultural-linguistic unity. 
In “La lengua española," Menéndez Pidal presents a concise yet dense description of Spanish and its history, concluding with a set of recommendations on the teaching of Spanish in the United States. His goal was to counter the emergence of autonomous cultural systems in Latin America, to demonstrate and naturalize the uniformity of Spanish, and to ascertain the integrity of the Hispanic literary field. Menéndez Pidal's historical and linguistic account reproduces colonial hierarchies and strives to project their currency on to a postcolonial scenario; but it also engages - even if in a backhanded manner - with contemporary theoretical debates within language studies. Methodologically grounded in positivism and philosophically influenced by idealism, the philologist represents the Spanish language as a historical construction born from the interaction between the heterogeneity of language, the natural evolution of linguistic forms, and human intervention. Interestingly, this representation was simultaneously embedded in an unequivocal coloniality and a socio-normative theory of language. Inasmuch as language is in the hands of its users, its nature - Menéndez Pidal's perspective implies - is social and political.

\section{Formalism and the sociolinguistics of Spanish in the United States}

Under the influence of Menéndez Pidal and a number of his disciples who held chairs in US universities, by the 1960s, the structure of Spanish departments was well established. Spanish was conceived as a foreign language, and it was to be taught so as to prepare students to engage intellectually with the literary canon. Students would become either Spanish teachers or, as scholars, join the ranks of non-Spanish Hispanists. ${ }^{1}$ Research on Spanish itself was focused either on the reconstruction of the language's evolution - in keeping with the patterns established by the Madrid School and its philological tradition - or on the contrastive grammar of Spanish and English in order to facilitate the learning of Spanish among English speakers. The sociopolitical - and even economic - dimension of language, acknowledged in some of Menéndez Pidal's work, was, however, absent from early Hispanic linguistics in North America.

The 1970s brought about a significant turn. First, the demographic weight of Latinxs in the United States - as well as inroads made by bilingual

1 As Degiovanni (ibid.) has shown, North American pan-Americanists banked on the commercial - more so than cultural - value of Spanish and saw students as future commercial and diplomatic mediators between the United States and Latin America. 
education - opened new topics of interest surrounding Spanish and led to higher registration in Spanish courses and to significant changes in the typical student body served by these departments. Second, with regards to developments in linguistics, the impact of communication-based theories of language acquisition, the generativist program's search for a formal model of a Universal Grammar underlying all languages - inexorably associated with Noam Chomsky - and the quantitative social dialectology of variationist sociolinguistics had a ripple effect on linguists working in Spanish departments. And third, Latin American literature scholars with intellectual projects that differed from those established by the Madrid School of Philology started to gain prominence in the United States, challenging established literary canons and bringing alternative outlooks to the study of literary production and reception.

In a now less philologically oriented environment, linguists in Spanish departments started to shift their focus. The history of the language and comparative grammar lost weight in favor of second-language acquisition, generativism, and the quantitative study of variation and contact between Spanish and English. The need to meet the growing demand for Spanish may have encouraged a focus on language acquisition and pedagogy as well as, perhaps, the fast adoption of communicative methods for language teaching (under the erroneous assumption that these required less teacher training than comparative grammar). Also, generativism's fast and solid establishment in US academia as a powerful intellectual program must have appealed to some of those already inclined toward language structure. And finally, the need to offer a pedagogical response to the linguistic profile of Latinx students must have further encouraged some to turn toward variationist sociolinguistics.

The central characteristics of linguistic research within Spanish departments in this period were its increasing isolation and scholars' academic legitimacy being contingent either on acceptance by "true" linguists - by and large located within linguistics departments - or on the development of Hispanic linguistics as an autonomous field. The establishment of the Hispanic Linguistics Symposium - first organized (by yours truly) at Miami University of Ohio in 1998 - and the development within the John Benjamins Publishing Company of the journal Spanish in Context - first published in 2004 - can be interpreted precisely as attempts to create venues for the institutionalization of Hispanic linguistics and, in the case of the latter, sociolinguistics. In both experiments, as a cursory look at conference programs and tables of contents reveals, the submission to the dictates of quantitative methods, positivism, and formal linguistics has been clear, and the isolation from colleagues in Spanish departments has only increased. 


\section{Cultural studies, critical theory, and Hispanic sociolinguistics' missed opportunities}

But different paths could have been taken. With the advent of cultural studies (CS) and critical theory (CT) in the 1970s and the 1980s, the language versus literature divide was further complicated. The literature section of Spanish departments split between an old guard that defended philological, historicistic, and positivistic approaches to the literary canon and new curricular proposals aimed at shifting the balance from one side of the Atlantic to the other and at bringing "theory" to bear into literary scholarship. The spread of CS and CT played into the hands of the latter group, as the adoption of this new approach was equated with the type of intellectual renewal well underway in English departments. At the same time, the CS/CT/Latin American shift was consistent with the United States' newly found interest in Latin American literature (the Latin American literary boom was a fairly recent phenomenon) and, increasingly, in things "Hispanic" - whatever that meant.

The irruption of CS and CT into Spanish departments created an opportunity for the cultivation of not just sociolinguistics but a critical sociolinguistics of Spanish. With regard to theory, the work of the Frankfurt School and literary and cultural theorists such as Bakhtin, Gramsci, or Raymond Williams, as well as the reconceptualizations of language by the likes of Bourdieu, Kristeva, Foucault, Derrida, or Judith Butler, offered effective tools to problematize the Saussurean paradigm of language study that favored system- and grammar-based approaches to language. At the same time, it engaged with alternative linguistic theorizations, such as integrationism (Harris 1982), emergent grammar (Hopper 1987), or the critical pathways opened by John Gumperz's interactionism discussed by Monica Heller in her introductory essay in this issue.

Similarly, as far as the study of language is concerned, CS and CT offered numerous pathways through which to channel sociolinguistics toward critical standpoints. The involvement of Spanish - both in its spoken and written form in social processes such as nationalism, imperialism, or class, gender, and racial inequality was consistent with concerns raised by critical theory. And "Spanish in the United States" was an obviously political object evidently embedded in North America's cultural political economy (Moraña 2005).

In spite of the actual creation of appropriate spaces - such as, for example, the Conference on Spanish in the United States held regularly since 1980 linguists working within Spanish departments have, by and large, failed to take these roads, and thus "Hispanic sociolinguistics" remains a doubly subsidiary field: looking for legitimization in disciplines articulated in other departments 
(linguistics) with greater institutional prestige and struggling for survival within departments (Spanish) whose intellectual mission is almost completely alien to positivistic and formalistic approaches to language.

As the university, as an institution, rearranges its social role - doing so under the impact of capitalism and the commodification of knowledge and culture - and as we witness sociopolitical upheavals where language plays a central role - such as the extreme mobilization of anti-immigrant sentiment or the distortion of the relationship between discourse and evidence - all scholars ought to recognize the historicity of knowledge production and sharpen our reflexive and critical gaze. For Hispanic sociolinguistics - as practiced within Spanish departments - failing to recognize our marginal position in the present academic landscape and, paradoxically, the political centrality of Spanish, both as a form of linguistic social practice and as an object of political action, will result in our academic demise and intellectual irrelevance.

\section{References}

Degiovanni, Fernando. 2018. Vernacular Latin Americanisms: War, the market, and the making of a discipline. Pittsburgh: University of Pittsburgh Press.

Harris, Roy. 1982. The language myth. London: Duckworth.

Hopper, Paul. 1987. Emergent Grammar. In Joan Aske, Natasha Berry, Laura Michaelis \& Hans Filip (eds.), Proceedings of the thirteenth annual meeting of the Berkeley linguistics society, 139-157. Berkeley: Berkeley Linguistics Society.

Moraña, Mabel. 2005. Introduction: Mapping Hispanism. In Mabel Moraña (ed.), Ideologies of Hispanism, ix-xxi. Nashville: Vanderbilt University Press.

Article note: This essay was originally published in Items: Insights from the Social Sciences, a publication of the Social Science Research Council. Del Valle, José. "Departments and Disciplinary Gatekeeping: The Sociolinguistics of Spanish in US Academia." In "Sociolinguistic Frontiers." Series, Items: Insights from the Social Sciences. https://items.ssrc.org/sociolinguistic-frontiers/ departments-and-disciplinary-gatekeeping-the-sociolinguistics-of-spanish-in-us-academia/. Reprinted with permission. 